\title{
The "Futuring" Dilemma in Narrative Identity: A Longitudinal Study of Future Vocational Plans Among Italian Freshmen
}

\author{
Luigia Simona Sica, Laura Aleni Sestito \\ University of Naples "Federico II", Naples, Italy
}

\begin{abstract}
The present study sought to explore the development of Psychology students' narrative vocational identity focusing on the future plans and expectations that led them to the choice of Psychology and identifying whether there are any developmental changes resulting from early experiences of university life. Written narratives produced by students were studied in two different moments: during the first week of university attendance and immediately after first session of exams. The participants consisted of 50 Italian psychology students, balanced by gender aged 18 to 21 years $\left(M_{\text {age }}=19.65\right.$ years, $\left.S D=2.28\right)$. Narrative data of both Time1 and Time2 were analysed and compared through a content analysis focusing on rationale for the selection of studies; temporal models; sophistication; and vocational identity process. The results suggest that the future vocational plans have a crucial role in the vocational identity development. In this sense, the present study gives important information in order to suggest vocational intervention to enhance the future orientation of university students.
\end{abstract}

Keywords: futuring, vocational identity, narrative approach, longitudinal study, young adults

\section{Introducation}

Choosing one's own working future and developing one's own vocational identity is a developmental task concerning young people in transition from late adolescence to adulthood (Porfeli, Lee, Vondracek, \& Weigold, 2011). This process also is intertwined with the development, in a more global view, of personal identity (Luyckx et al., 2008) and it is affected in a concrete way by the historical, economic and cultural environment in which the individual grows. For these reasons, in some contexts particularly exposed to the economic crisis of recent years, this process has become more and more problematic and difficult, a source of discomfort and stress (Berman \& Montgomery, 2014). Research findings documented for young people show that, even though they have decided to prolong their studies and invest in specialized post-graduate university studies and training courses, the presence of identity postponement (Crocetti, Rabaglietti, \& Sica, 2012) in some cases is linked to identity distress and anxiety (Sica, Aleni Sestito, \& Ragozini, 2014) and to a general sense of discomfort in future plans and present focusing (Adams, 2009; Leccardi, 2006). However, our question is how young people, in a context of poor career and work opportunities, can explore and commit their vocational identity and how they can build a clear sense of who they are and where they are going in their lives. Indeed, on the basis of this evidence a new problematic area of identity development could be identified for students in the intersection between vocational identity development, contextual occupational opportunities and personal time-perspective.

Luigia Simona Sica, Ph.D., Department of Humanities, University of Naples "Federico II".

Laura Aleni Sestito, Professor, Department of Humanities, University of Naples "Federico II". 
This problematic area will be the object of the current study and we shall refer to it as "the futuring dilemma in narrative vocational identity development". The purpose of this study was to explore the processes leading to the choice of the individual's own future occupation and vocational identity achievement in contexts that are unattractive in terms of immediate employment opportunities, and to identify what factors may be involved in vocational identity achievement, in addition to what factors can be identified in a state of identity diffusion or moratorium. In doing so, we referred to the narrative identity paradigm.

\section{Defining Vocational Identity: A Developmental Task}

Vocational identity is conceived as a domain-specific aspect of identity as a whole, providing young people with a framework for the regulation of its objectives and at the same time for self-regulation (Hirschi, 2012). Vocational identity is, therefore, believe to be a defining feature in adolescent and young adult life and appears to be a central element of identity (Skorikov \& Vondraceck, 2011) and the major component of one's overall sense of identity (Kroger, 2007; Skorikov \& Vondraceck, 2007). People exhibiting an advanced identity-status show greater career planning and decidedness (Wallace-Broscious, Serafica, \& Osipio, 1994) and a developing vocational identity appears to contribute to overall identity (Kroger, 1988; Skorikov \& Vondracek, 1998), which was proposed by Grotevant (1987) and confirmed for the vocational domain (Meeus, 1993; Skorikov \& Vondracek, 1998). Numerous studies also confirm the positive association between occupational identity and more general conceptions of identity in adolescence and young adulthood (Nauta \& Kahn, 2007; Savickas, 1985). Empirical studies have found that the engaging in occupational exploration and making occupational commitments promote identity development from childhood through adulthood (Flum \& Bluestein, 2006; Kroger, 2007; Skorikov \& Vondracek, 2007). Work was found to be the primary influence on overall identity for college students, workers and unemployed (Danielsen, Loren, \& Kroger, 2000).

Despite the general regularity of vocational identity development exhibited on the population level across the adolescent and early adulthood period, there exists a great deal of variability in terms of the pathways and timing of vocational identity progress. The nature of career progress is shifting away from a hierarchical series of roles/jobs within an employer yielding increased status and responsibility and moving toward a series of jobs/projects within and across employers. Career progress as a series of jobs and titles becomes re-defined as an ever expanding repertoire of skills and a multiplying professional network. This shift brings new opportunities and challenges associated with lifespan identity development.

\section{Narrative Identity: Meaning Making and Autobiographical Times}

The narrative identity approach places specific emphasis on individuals' subjective assessment of their personal experiences and the stories that they tell about them (McAdams, 1993). The autobiographical narratives enable individuals to structure their experiences in a format that facilitates subjective reflection, and thus, the process of making sense of life or of life's specific events, which is critical to identity development (Bruner, 1993; Kunnen \& Bosma, 2000). This narrative "meaning making" has been proposed as one of the major processes by which identity is constructed and as behaviour that reflects the current state of an individual's identity (McLean, Pasupathi, \& Pals, 2007). In this study we referred, in addition to the meaning making assumption, to the conceptualization of "autobiographical time" (Brockmeier, 2000) (see Table 1) which interprets identity as a result of the interaction process between continuity and discontinuity through time and space (Lichtwark-Aschoff, van Geert, Bosma, \& Kunnen, 2008) and autobiographical discourse as the form 
par excellence in which we give shape to the time of our life (Brockmeier, 2000; Sica, Brockmeier, \& Aleni Sestito, 2010). In this sense, we agree with the idea that such an identity takes on the form of a well-structured story that explains "how the self of yesterday became the self of today and will become the self of tomorrow" (Savickas, 2005, p. 58).

Table 1

Authobiographical Time and Narratives Models (see Brockmeier, 2000)

\begin{tabular}{|c|c|c|c|}
\hline Authobiographical time & Narrative models & Developmental models & Description \\
\hline \multirow[t]{3}{*}{$\begin{array}{l}\text { In the process of } \\
\text { autobiographical identity } \\
\text { construction a particular } \\
\text { synthesis of cultural and } \\
\text { individual orders of time takes } \\
\text { place. The result is } \\
\text { autobiographical time, the time } \\
\text { of one's life (Brockmeier, } \\
2000, \text { p. 51). }\end{array}$} & \begin{tabular}{|l} 
Several narrative models of \\
autobiographical time, each \\
suggesting a particular vision \\
of the course and direction of \\
time.... In aligning actions and \\
events along long-term \\
episodic structures, they give a \\
meaningful diachronic order to \\
a selected multitude of singular \\
life events. Put the other way \\
around, only by being \\
integrated into a particular \\
gestalt of order and coherence, \\
life events become meaningful \\
(Brockmeier, 2000, p. 61).
\end{tabular} & & \\
\hline & & $\begin{array}{l}\text { (a) Developmental models } \\
\text { (linear, circular, cyclic, spiral) }\end{array}$ & $\begin{array}{l}\text { They describe life as process, } \\
\text { movement and, through them, } \\
\text { the autobiography can be read as } \\
\text { a place for a developmental } \\
\text { organization of both time and } \\
\text { experience. }\end{array}$ \\
\hline & & $\begin{array}{l}\text { (b) Not-developmental } \\
\text { models (static and } \\
\text { fragmentary) }\end{array}$ & $\begin{array}{l}\text { They lack a development } \\
\text { trajectory and they do not seem } \\
\text { to contain dynamics of change: } \\
\text { they are, essentially, "timeless". }\end{array}$ \\
\hline
\end{tabular}

\section{Late Adolescents and Young Adults in Italy: Peculiarities of Mediterranean Countries}

In this study we refer to the particularly difficult job market that characterizes the Italian context for young people. Italy was chosen as a prototype of Southern European countries wherein young people's possibilities to develop coherent and fulfilling future plans are strongly threatened by the current socio-economic situation (Leccardi, 2006). The main problems that affect Southern European youth include high rates of unemployment (ranging approximately from 35\% to 55\%; Eurostat, 2015); large numbers of youth classified as "Not in Education, Employment, or Training" (NEET) (Bynner \& Parson, 2002); widespread job precariousness (e.g., Cortini, Tanucci, \& Morin, 2011); and a deep-rooted crisis of confidence in the social institutions (e.g., Pharr \& Putnam, 2000). All these problems can be observed in the Italian context that is characterized by a particularly difficult job market for young people (Aleni Sestito, Sica, \& Nasti, 2013). In fact, even after concluding their prolonged programs of study, these young people have been found to experience additional periods of instability, insecurity, and economic uncertainty (Berton, Richiardi, \& Sacchi, 2009; Iezzi \& Mastrobuoni, 2010; $\left.\operatorname{ISTAT}^{1}, 2014\right)$.

\footnotetext{
1 The National Statistics Institute (ISTAT) is a governmental research organization. It has been in existence since 1926 and it is the main producer of official statistics in support of citizens and decision makers. It works independently and in continuous interaction with the academic and scientific worlds.
} 
Given the challenging social and economic contexts in which Italian youth live, it is not surprising that we are noting changes in developmental pathways. For example, when compared to their Northern European peers, Italian late adolescents and young adults demonstrate a postponement of identity choices (Crocetti, Rabaglietti, \& Sica, 2012; Sica, Aleni Sestito, \& Ragozini, 2014). Furthermore, the image of the future as a controllable and governable time is shrinking, and as a result, "the present looks like the only temporal dimension available for defining choices, an authentic existential horizon that, in a certain sense, includes and replaces future and past" (Leccardi, 2006, p. 41).

A consequence of the unpredictable social and developmental context in Southern Europe, as in all contexts characterized by high levels of job insecurity, unemployment, and a general distrust in political institutions, family represents the main social safety net (Albertini \& Kohli, 2013). In Southern Europe specifically, the family plays a central role in the welfare system, acting as the main provider of care and welfare for young people (e.g., familism, Saraceno, 2003); therefore, in Italy relationships with family are often considered more important than relationships with friends, and parents play a critical role in the identity development and future planning of their children (Aleni Sestito \& Sica, 2014).

\section{The Present Study}

In the Italian context, despite the job market crisis, and specifically the uncertainty of job opportunities for psychologists, many students choose to enrol in the Psychology Faculty (as cited in ISTAT, 2013). The present study sought to explore the development of Psychology students' narrative vocational identity by focusing on the future plans and expectations that led them to the choice of Psychology, and by identifying whether there are any developmental changes resulting from early experiences of university life. Indeed, the purpose of the present longitudinal study was to explore the challenge of narrative vocational identity during their first year at university when freshmen face many new features that could activate processes of self-reflection, analysis and revision of the choices just made with a view to modifying or consolidating them. Based on the narrative approach (Pasupathi, Wainryb, \& Twali, 2012), narratives produced by students were studied in two different moments, in other words Time 1 during the first week of university attendance, and Time 2 in the week after the first examinations session.

Specifically the research questions we posed were the following:

(1) Starting from such expectations and motivations, did students formulate their projects about psychology despite the specific difficulties in employment access?

(2) What changes were induced by university life experiences in the first semester?

(3) What are the processes by which Italian psychology freshmen develop their vocational identity?

We expected that during the time-frame between Time 1 and Time 2 freshmen have to face many new meaningful features that could activate processes of self-reflection, analysis and revision of their choices just made and commitment reconsiderations.

\section{Method}

\section{Participants}

The participants consisted of 50 Italian university students, balanced by gender aged 18 to 21 years $\left(M_{\mathrm{age}}=\right.$ 19.65 years, $S D=2.28$ ) who completed a two-wave longitudinal study. They were all students attending the first year of psychology university courses in a large Italian city. Participation in the study was voluntary and anonymity was guaranteed. 


\section{Measure}

We used the following narrative prompt: Tell me the path that led you to choose this course of study: what projects, what hopes, what future.

\section{Results}

Narrative data of both Time1 and Time2 were analysed and compared through a content analysis focusing on: (a) vocational choice in terms of rationale for the selection of studies and vocational identity process; (b) narrative identity in terms of planning for the future, autobiographical times and meaning making level (see Table 2).

Table 2

\section{Coding Template}

\begin{tabular}{|l|l|l|}
\hline Research questions & Category & Thematic category \\
\hline Vocational choice & 1. Rational & Descriptive subcategory \\
\hline 2. Vocational Identity & $\begin{array}{l}\text { Commitment } \\
\text { Explorations } \\
\text { Reconsideration: flexibility and self-doubt } \\
\text { (Porfeli et al., 2011) }\end{array}$ \\
\hline Narrative development & $\begin{array}{l}\text { Balance } \\
\text { Past experiences } \\
\text { Futuring } \\
\text { Narrative models of autobiographical time } \\
\text { (Sica, Brockmeier, Aleni Sestito, 2010): } \\
\text { (a) Developmental models } \\
\text { (b) Not-developmental models }\end{array}$ \\
\hline & 1. Autobiographical time & Scale 0 to 3 \\
\hline
\end{tabular}

The content analysis revealed that all students referred to intrinsic motivation (see Figure 2).
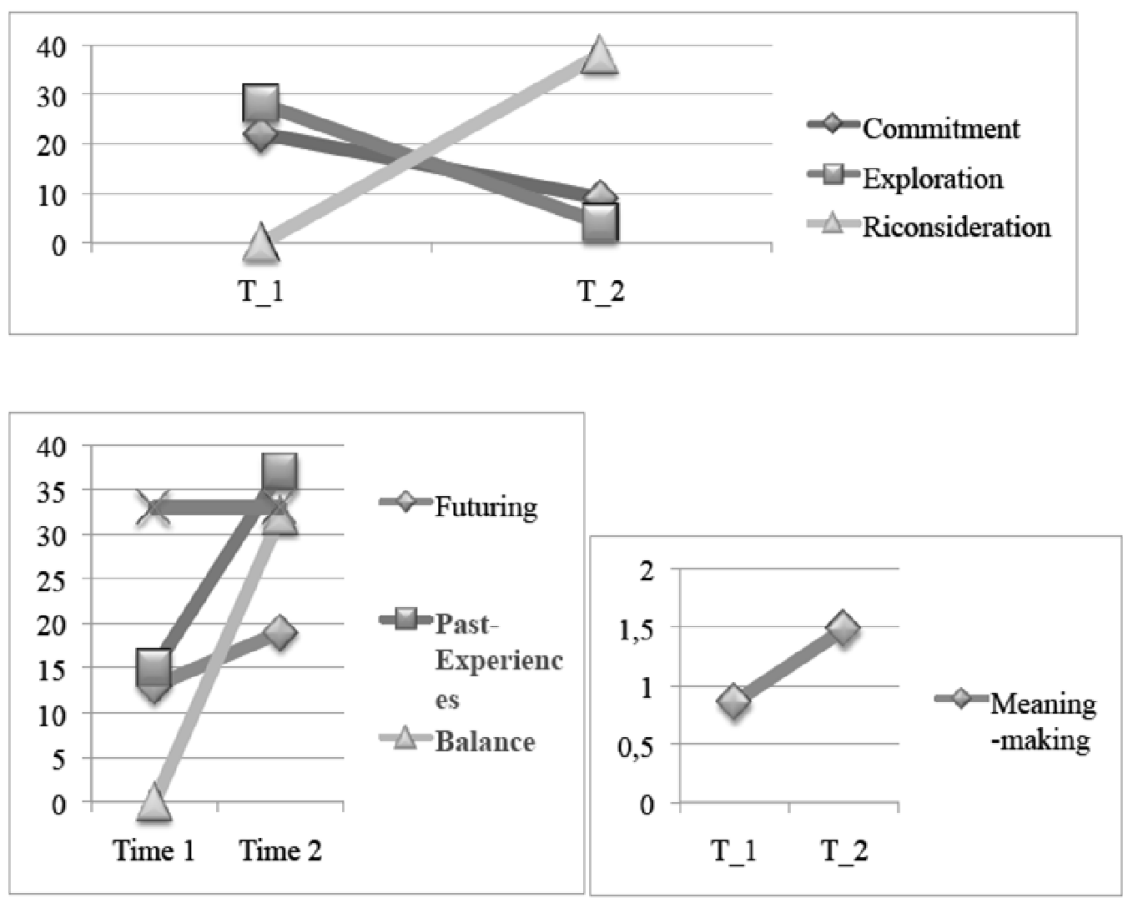

Figure 1. Vocational Identity dimensions, Autobiographical Time and Meaning Making in the two times of the study. 


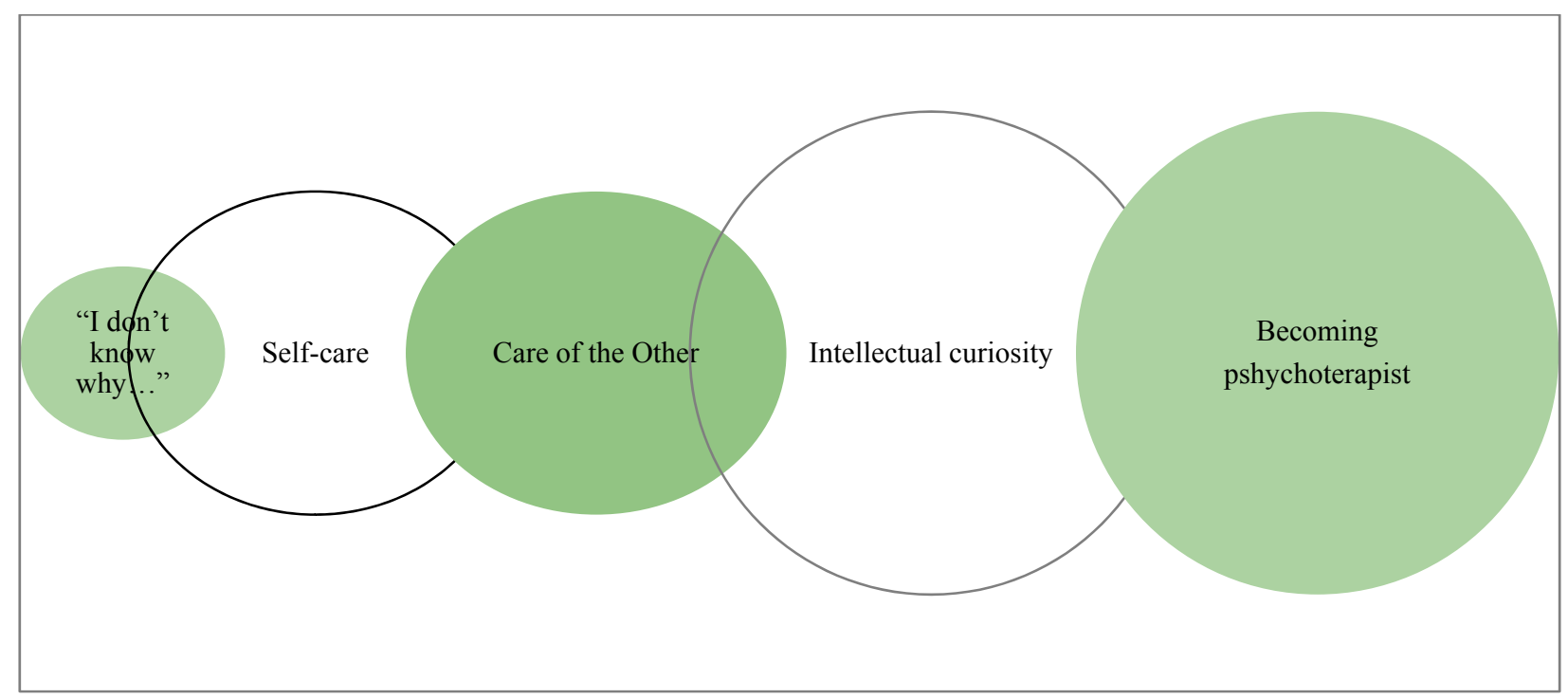

Figure 2. Rational for vocational choice: Intrinsic motivation.

Our results show that insofar as identity processes are concerned from Time 1 to Time 2, Commitment $\left(\chi^{2}\right.$ = 7.22; Sig. $=0.007)$ and Exploration decreased $\left(\chi^{2}=25.3\right.$; Sig. $\left.=0.000\right)$ but Reconsideration processes (in terms of both Flexibility and Self-doubt $)$ increased $\left(\chi^{2}=54.65\right.$; Sig. $\left.=0.00\right)$. The results have also shown significant increase in the dimensions of meaning-making. Autobiographical time resulted as developmental and did not show changes from time one to time two.

\section{Two Sides of Vocational Identity Development: The Coloured One and the Dark One}

The changes of the considered dimensions allowed us to identify two trajectories of vocational identity development differently characterized by the presence/absence of future vocational plans (Figure 3). Trajectory a. has a "positive" outcome; trajectory b. (in which no future plans were found) has a "negative" outcome in identity terms. Both trajectories, in turn, influence the kind (flexible or self-doubt characterized) of reconsideration in which students are still involved (Table 3).

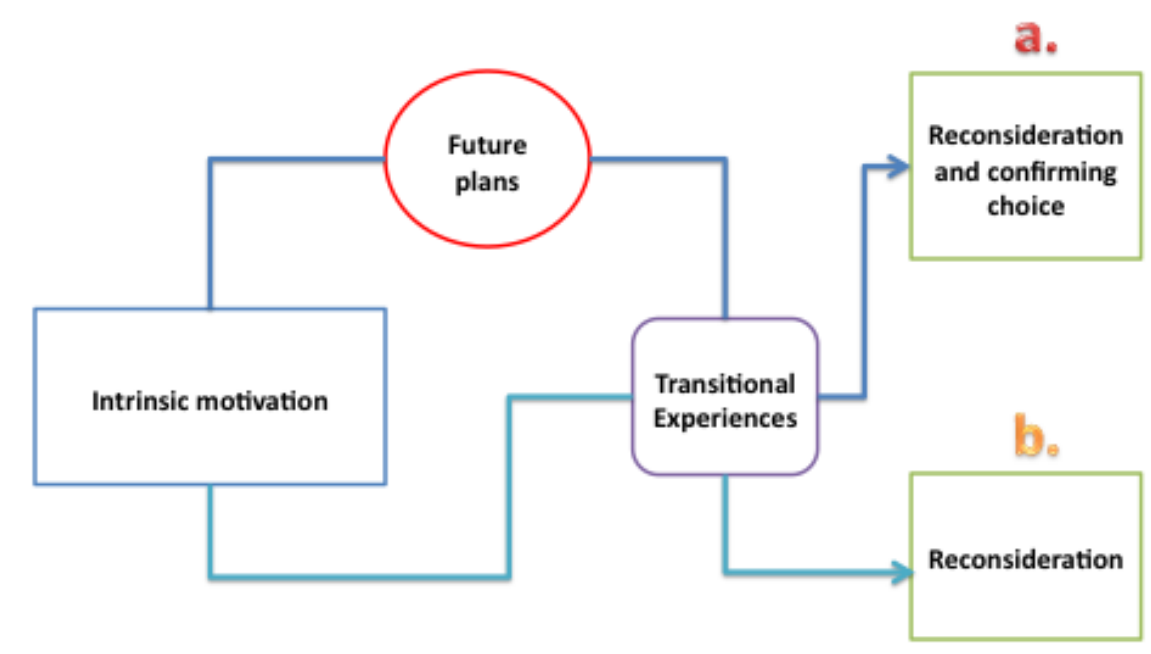

$\mathrm{T1}$

Figure 3. The trajectories of vocational identity development. 
Table 3

Narrative Examples of the Two Vocational Development Trajectories

\begin{tabular}{|l|l|}
\hline Trajectories & Narrative excerpt \\
\hline a. Reconsideration and confirming choice & $\begin{array}{l}\text { At the start I had a clearer picture of my goals and the work I wanted to do, but } \\
\text { since I've been at university a whole new world has opened itself up to me... } \\
\text { While before the only thing I had in mind was the figure of a psychotherapist, } \\
\text { now I have a much wider view. I think I need more time; but for the moment I } \\
\text { aim to study hard in order to achieve my dream (F, T2) }\end{array}$ \\
\hline b. Reconsideration with self-doubt & $\begin{array}{l}\text { The choice I'm following was not carefully thought through, nor the result of a } \\
\text { long process. I was obliged to make a choice because time was running out.... } \\
\text { Today I can say that I find the subject matter very stimulating, but my fears are } \\
\text { still there. Above all I don't feel I can see a clear hope for the future simply } \\
\text { because I just don't know what to hope for, and I don't know who I want to } \\
\text { become or who I can become... (F, T2) }\end{array}$ \\
\hline
\end{tabular}

\section{Discussion and Clinical Implications: How This Study Provides a Better Understanding of Problematic Identity Formation}

This contribution was designed to shed light on development of Psychology students' narrative vocational identity by focusing on the future plans and expectations that led them to the choice of Psychology, in a longitudinal perspective. In order to do that, we adopted a narrative approach to explore the meaning making processes that the transitional phase in which students are involved could activate. Findings show three main interesting results: the modification of identity processes during the transition considered; the crucial role of futuring on the definition of vocational identity and the presence of two different trajectories; the prevalence of intrinsic motivation for psychology choice.

First, results showed that the new relational and individual experiences offered by university context have an impact on vocational identity processes of participants. Specifically, an increasing of identity reconsideration processes was found. This result is in line with the development of identity processes during biographical transition that are significant for the balance between plans and actual experiences. More specifically, the increasing of reconsideration processes accords with the results of Italian researches that showed that a large fraction of the university students were classified in the searching moratorium and undifferentiated vocational identity statuses perhaps because they continue to wrestle with establishing a sense of self at work in a socio-economic context that has very limited work opportunities. Within a university system in which all the students in this study had chosen a college major, these results suggest that only a fraction of these had committed to a career. This discrepancy between academic and career commitments speaks to the increasing lack of confidence that Italian young adults have in an educational system that presently leads to very limited work opportunities (Aleni Sestito et al., 2015; Sica et al., 2014).

Second, based on the described results, future vocational plans seem to have a crucial role in vocational identity development. In this sense, the present study suggests vocational support schemes to enhance the future orientation of students and their skill in planning their future occupation in order to prevent identity irresolution and negative reconsideration, as well as to support flexibility and identity achievement. Indeed, the current study reveals the crucial role of "futuring" (the capacity to make future plans; Sica, Crocetti, Aleni Sestito, Ragozini, \& Serafini, 2016) in self-definition. This evidence supports the contention of identity research that emphasizes the importance of the identity exploration and the orientation to the future to support vocational and occupational future choices (Oyserman, Bybee, Terry, \& Hart-Johnson, 2004). 
Third, it could be interesting to note that, in times of economic and employment crisis, the motivation involved in choosing the vocational trajectory is "intrinsic". However, intrinsic motivation is not enough. Students need to make future plans in order to reconsider, explore and confirm their vocational identity. Otherwise this intrinsic motivation seems to be an unrealistic aspiration that may not be strong enough to resist comparison with reality. However, we believe students are still evolving: they are still involved in identity formation and their autobiographical models are all developmental.

According to the above evidence, we suggest that practical programmes of identity-confusion prevention for university students could focus on future orientation improvement and identity development support, specifically allowing and supporting them in their ability to shape a personal project and a realistic vision of vocational possible selves. As described by the two trajectories, the ability to shape their own projects could impact on the outcome of identity reconsideration in transitional moments. Planning themselves for the future provides students with the support to create their vocational identity without identity distress.

\section{Limitations and Future Direction of Research}

At the moment, the study described here has a number of limitations because it is the first step of a larger research programme. Firstly, in this paper we presented data of only psychology students. In the next step of our research the data from a broad sample of students will be examined to frame the study within general problems in the job market in Italy. Furthermore, we used two steps for data collection in this paper, and now we are analysing the third set of data already collected, in other words Time3. Despite these limitations, the current findings have many important conceptual and practical implications. First, the current study provides support for counseling initiatives to help individuals design and redesign their lives (Collin \& Guichard, 2010). Specifically, our findings indicate that university students need support to develop their identity and plan their future in an adaptive way (Sica et al., 2014). These findings also advance the literature, confirming there is a link between identity formation and difficulties in university students in Italy (Sica et al., 2014). They point to the need to specifically target identity formation processes for the prevention of academic difficulties, developmental moratorium and psychological distress. This suggests that particularly for students who are unable to capitalize on the opportunities presented by the university context, intervention programs may be necessary to promote identity consolidation, the exploration of possible selves (Sica, 2009) and the identification of adult roles and commitments. In this sense, our results support the specificity of identity construction and career development initiatives for young adults as planned in the international context (Guichard, Pouyaud, de Calan, \& Dumora, 2012).

\section{References}

Adams, J. (2009). The mediating role of time perspective in socio-economic inequalities in smoking and physical activity in older English adults. Journal of Health Psychology , 14, 794-799. doi: 10.1177/1359105309338979

Albertini, M., \& Kohli, M. (2013). The generational contract in the family: An analysis of transfer regimes in Europe. European Sociological Review, 29(4), 828-840. doi:10.1093/esr/jcs061

Aleni Sestito, L., \& Sica, L. S. (2014). Identity formation of Italian emerging adults living with parents: A narrative study. Journal of Adolescence, 37, 1435-1447.

Aleni Sestito, L., Sica, L. S., \& Nasti, M. (2013). The generation of youth without work: Transitions to adulthood in conditions of precariousness, unemployment and underemployment. Ricerche di Psicologia, 3, 411-444.

Aleni Sestito, L., Sica, L. S., Ragozini, G., Porfeli, E., Weisblat, G., \& Di Palma, T. (2015). Vocational and overall identity: A person-centered approach in Italian university students. Journal of Vocational Behavior, 91, 157- 169. 
Berman, S. L., \& Montgomery, M. J. (2014). Problematic identity processes: The role of identity distress. Identity: An International Journal of Theory and Research, 14(4), 41-245. doi:10.1080/15283488.2014.944700

Berton, F., Richiardi, M., \& Sacchi, S. (2009). Flex-insecurity: Perché in Italia la flessibilità diventa precarietà (Why flexibility becames Insecurity in Italy). Bologna: Il Mulino.

Brockmeier, J. (2000). Autobiographical time. Narrative Identity, 51-73.

Bruner, J. S. (1993). The autobiographical process. In R. Folfenflik (Ed.), The culture of autobiography: Construction of self-representation (pp. 38-56). Standford: Standford University Press.

Bynner, J., \& Parsons, S. (2002). Social exclusion and the transition from school to work: The case of young people not in education, employment, or training (NEET). Journal of Vocational Behavior, 60(2), 289-309. doi:10.1006/jvbe.2001.1868

Collin, A., \& Guichard, J. (2010). Constructing self in career theory and counseling interventions. In P. J. Hartung, \& L. M. Subich (Eds.), Constructing self in work and career (pp. 89-106). Washington, D.C.: APA Books.

Cortini, G., Tanucci, \& Morin, E. (Eds.) (2011). Boundaryless careers and occupational well-being: An interdisciplinary approach. Houndmills: Palgrave MacMillan.

Crocetti, E., Rabaglietti, E., \& Sica, L. S. (2012). Personal identity in Italy. New Directions for Child and Adolescent Development, 138, 87-102. doi: 10.1002/cad.20023

Danielsen, L. M., Lorem, A. E., \& Kroger, J. (2000). The impact of social context on the identity-formation process of Norwegian late adolescents. Youth \& Society, 31, 332-362.

Flum, H., \& Blustein, D. L. (2006). Reinvigorating the study of vocational exploration: A framework for research. Journal of Vocational Behavior, 56, 380-404.

Grotevant, H. D. (1987). Toward a process model of identity formation. Journal of Adolescent Research, 2, $203-222$.

Guichard, J., Pouyaud, J., de Calan, C., \& Dumora, B. (2012). Identity construction and career development interventions with emerging adults. Journal of Vocational Behavior, 81, 52-58.

Hirschi, A. (2012). Vocational identity trajectories: Difference in personality and development of well-being. European Journal of Personality, 26(2), 12.

Iezzi, M., \& Mastrobuoni, T. (2010). Gioventù sprecata (Wasted youth). Milano: Laterza.

ISTAT (Istituto Nazionale di Statistica). (2014). Press Release. Retrieved the 30th, 2014 from www.istat.it.

Kroger, J. (1988). A longitudinal study of ego identity status interview domains. Journal of Adolescence, 11(1), 49-64.

Kroger, J. (2007). Identity development: Adolescence through adulthood (2nd ed.). Thousand Oaks, C.A.: Sage.

Kunnen, E., \& Bosma, H. (2000). Development of meaning making: A dynamic systems approach. New Ideas in Psychology, 18(1), 57-82. doi: 10.1016/S0732-118X(99)00037-9

Leccardi, C. (2006). Redefining the future: Youthful biographical constructions in the 21st century. New Directions for Child and Adolescent Development, 113, 37-48. doi: 10.1002/cd.167

Lichtwarck-Aschoff, A., van Geert, P. L. C., Bosma, H. A., \& Kunnen, E. S. (2008). Time and identity: A framework for research and theory formation. Developmental Review, 28, 370-400.

Luyckx, K., Schwartz, S. J., Berzonsky, M. D., Soenens, B., Vansteenkiste, M., Smits, I., \& Goossens, L. (2008). Capturing ruminative exploration: Extending the four-dimensional model of identity formation in late adolescence. Journal of Research in Personality, 42(1), 58-82. doi: 10.1016/j.jrp.2007.04.004

McAdams, D. (1993). The stories we live by: Personal myths and the making of the self. New York: Morrow.

McLean, K. C., Pasupathi, M., \& Pals, J. L. (2007). Selves creating stories creating selves: A process model of narrative self development in adolescence and adulthood. Personality and Social Psychology Review, 11, 262-278.

Meeus, W. (1993). Occupational identity development, school performance, and social support in adolescence: Findings of a Dutch study. Adolescence, 28(112), 809-818.

Nauta, N. M., \& Kahn, J. H. (2007). Identity status, consistency and differentiation of interest and career decision self-efficacy. Journal of Career Assessment, 15(1), 55-65.

Oyserman, D., Bybee, D., Terry, K., \& Hart-Johnson, T. (2004). Possible selves as roadmaps. Journal of Research in Personality 38(2), 130-149. doi:10.1016/S0092-6566(03)00057-6

Pasupathi, M., Wainryb, C., \& Twali, M. (2012). Narrative construction of ethnicity-based discrimination and its relationships to ethnic identity exploration and commitment in ethnic majority and minority members. Identity: An International Journal of Theory and Research, 12, 53-73.

Pharr, S. J., \& Putnam, R. D. (Eds.). (2000). Disaffected democracies: What is troubling the what's troubling the trilateral countries? Princenton, N.J.: Princenton University Press. 
Porfeli, E., J., Lee, B., Vondracek, F., W., \& Weigold, I., K. (2011). A Multidimensional measure of vocational identity status. Journal of Adolescence, 34, 853-871.

Saraceno, C. (2003). Family changes and social policies in Italy. Bologna: il Mulino.

Savickas, M. L. (2005). The theory and practice of career construction (pp. 42-70). In S. D. Brown, \& R. W. Lent (Eds.), Career development and counseling: Putting theory and research to work. Hoboken, N.J.: John Wiley \& Sons.

Savickas, M. L. (1985). Identity in vocational development. Journal of Vocational Behavior, 27, 329-337.

Sica, L. S. (2009). Adolescents in different contexts: The exploration of identity through possible selves. CBB-Cognition, Brain and Behavior: An Interdisciplinary Journal, XIII(3), 221-252.

Sica, L. S., Aleni Sestito, L., \& Ragozini, G. (2014). Identity coping in the first years of university: Identity diffusion, adjustment and identity distress. Journal of Adult Development. doi: 10.1007/s10804-014-9188-8

Sica, L. S., Brockmeier, J., \& Aleni Sestito, L. (2010). La costruzione dell'identità narrativa nelle transizioni biografiche normative e non normative: Analisi della struttura temporale (Narrative identity construction in normative and non normative biographical transitions). Psicologia Scolastica, 9(1), 15-37.

Sica, L. S., Crocetti, E., Aleni Sestito, L., Ragozini, G., \& Serafini, T. (2016). Future-oriented or present-focused? The role of social support and identity styles on "futuring" in Italian late adolescents and emerging adults. Journal of Youth Studies, 19(2), 183-203, DOI: 10.1080/13676261.2015.1059925

Skorikov, V. B., \& Vondracek, F. W. (2007). Vocational identity. In V. B. Skorikov, \& W. Patton (Eds.), Career development in childhood and adolescence (pp. 143-168). Rotterdam: Sense Publishers.

Skorikov, V. B., \& Vondracek, F. W. (2011). Occupational identity. In S. J. Schwartz, K. Luyckx, \& V. L. Vignoles (Eds.), Handbook of identity theory and research (pp. 693-714). New York: Springer.

Skorikov, V. B., \& Vondracek, F. W. (1998). Vocational identity development: Its relationship to other identity domains and to overall identity development. Journal of Career Assessment, 6, 13-35.

Wallace-Broscious, A., Serafica, F. C., \& Osipio, S. H. (1994). Adolescent career development: Relationship to self-concept and identity status. Journal of Research on Adolescence, 4(1), 127-149. 